\title{
DETERMINAN RETURN ON ASSETS BANK BNI SYARIAH: PENDEKATAN ERROR CORRECTION MODEL
}

\author{
Deby Marlistyawati Putri ${ }^{1}$, Maulida Nurhidayati ${ }^{2}$, Nurul Khasanah ${ }^{3}$ \\ 1,2,3 Institut Agama Islam Negeri Ponorogo, Indonesia \\ Email: Debymarlistyaputri@gmail.com ${ }^{1}$, nurhidayati@iainponorogo.ac.id ${ }^{2}$, \\ khasanah@iainponorogo.ac.id ${ }^{3}$
}

\begin{abstract}
Return on Assets at BNI Syariah banks has shown poor performance. If this condition continues, it can have a destructive impact and result in many losses that must be borne. The study was conducted to determine the effect of mudharabah deposits, equity, and size on Return on Assets at BNI Syariah Bank. The research was conducted with a quantitative approach on quarterly data published by BNI Syariah, OJK, and BI for 2012-2019. The analysis technique uses the Error Correction Model (ECM). The results obtained indicate that mudharabah deposits and equity in the short and long term do not affect ROA. Size in the short term has no effect but in the long term affects ROA. Simultaneously, mudharabah deposits, equity, and size affect ROA both in the short and long term. The contribution amount given is $31.74 \%$ in the short term and $49.51 \%$ in the long term. BNI Syariah Bank can further increase customer interest in deposits, expand market share in larger-scale business units and the general public, and use promotional media more creatively according to the digital era.
\end{abstract}

Keywords: ROA, Mudharabah Deposits, Equity, Size

Abstrak : Return on Assets pada bank BNI Syariah telah menunjukkan performansi kurang baik. Jika kondisi ini terus berlangsung dapat berdampak buruk serta berakibat pada besarnya kerugian yang harus ditanggung. Penelitian dilakukan untuk mengetahui pengaruh deposito mudharabah, ekuitas, dan size terhadap Return on Assets pada Bank BNI Syariah. Penelitian dilakukan dengan pendekatan kuantitatif pada data triwulan yang dipublikasikan oleh BNI Syariah, OJK dan BI periode 2012-2019. Teknik analisis menggunakan Error Correction Model (ECM). Hasil yang diperoleh menunjukkan bahwa deposito mudharabah dan ekuitas pada jangka pendek maupun jangka panjang tidak berpengaruh pada ROA. Size dalam jangka pendek tidak berpengaruh tetapi dalam jangka panjang berpengaruh pada ROA. Secara simultan, deposito mudharabah, ekuitas dan size berpengaruh pada ROA baik dalam jangka pendek maupun jangka panjang. Besarnya kontribusi yang diberikan adalah 31,74\% pada jangka pendek dan 49,51\% pada jangka panjang. Bank BNI Syariah dapat lebih meningkatkan minat nasabah pada deposito, memperluas market share pada unit usaha skala lebih besar serta masyarakat umum lainnya dan penggunaan media promosi sesuai era digital dengan lebih kreatif.

Kata Kunci: ROA, Deposito Mudharabah, Ekuitas, Size

\section{PENDAHULUAN}

Aktivitas atau kegiatan perekonomian dalam islam sangat beraneka ragam, dengan begitu terdapat kaidah - kaidah terstruktur dengan berpedoman terhadap hukum islam. Hadirnya ilmu syariah dan pendukungnya sebagai penguat bagi kegiatan ekonomi memiliki hubungan yang begitu erat terhadap perilaku manusia. Lingkungan 
ekonomi memiliki pergerakan yang tidak jauh dari permainan uang sesuai fungsi serta tepat akan sasaran. Hadirnya perbankan menjadi salah satu penggerak roda perekonomian di Indonesia yang melakukan permainan uang sesuai aturan dan sasaran yang tepat sesuai syariat islam dengan sistem bagi hasil bukan riba. Oleh karena itu, kini kian banyak berdirinya perbankan yang berlandaskan kaidah dan hukum syariah.

Bank sebagai lembaga keuangan yang sangat strategis dengan peran pentingnya dalam perkembangan perekonomian negara. Adanya sistem bagi hasil terhadap bank syariah guna meminimalkan risiko usaha dengan berbagi hasil pada usaha (Ismail, 2020). Dari segi usaha, lembaga keuangan seperti bank syariah tidak lepas dari pertumbuhan market share dilihat dari pertumbuhan jumlah aset yang dimiliki. Setiap tahunnya aset akan bertambah dan memerlukan pengelolaan investasi yang terorganisir. Hal ini yang membuat perbankan begitu rentan terjadinya risiko. Disamping itu, bank sebagai lembaga intermediasi yang harus selalu melakukan prinsip kehati - hatian dalam menjaga hubungan kedua belah pihak. Dengan begitu, perlu adanya pengukuran pada kinerja bank biasanya menggunakan rasio profitabilitas dengan menunjukkan besaran laba yang akan dimanfaatkan terhadap sumber daya yang ada (Wahyuni, 2019).

Profitabilitas dapat diukur melalui Return on Assets (ROA) yang memiliki hubungan erat terhadap laba dengan aktiva yang dipergunakan dalam menilai penggunaan aktiva. ROA dapat menilai kemampuan Bank Syariah dari penghasilan keuntungan pada masa sebelumnya untuk dapat dimanfaatkan pada masa mendatang atau periode kepedannya. Rasio ini menunjukkan perkiraan besar keuntungan bersih yang diperoleh Bank Syariah berdasarkan dari nilai aktiva. Penelitian tentang ROA sudah banyak dilakukan karena ukuran ini sangat penting untuk mengukur keberhasilan suatu Bank Syariah (Apriyanti, Rahman, \& Maharani, 2021; Awintasari \& Nurhidayati, 2021; Indriwati \& Purwana, 2021; Pravasanti, 2018; Rahmawati, 2017; Riyanto \& Asakdiyah, 2020). Penelitian terdahulu ini menunjukkan bahwa penelitian tentang ROA terus mengalami perkembangan dari waktu ke waktu dan masih menjadi penelitian yang menarik untuk terus dilakukan penelitian.

Menurut Kasmir, ROA dipengaruhi oleh margin laba bersih dan total aktiva (Kasmir, 2014). Usaha dalam meningkatkan ROA dapat dilakukan dengan meningkatkan investasi dana pada aktiva lancar maupun aktiva tetap. Aktiva lancar ini dapat berwujud deposito dan surat berharga seperti saham, obligasi, serta surat hipotek (Hidayat, 2018). Menurut Rihfenti Ernayani, dkk menyebutkan bahwa ROA 
dipengaruhi oleh faktor internal dan faktor eksternal. Faktor internal meliputi manajemen modal, penghimpunan dana, manajemen likuiditas, dan manajemen biaya. Sedangkan faktor eksternal terdiri dari JUB, inflasi, ukuran bank (size), nilai tukar, dan lain-lannya. (Ernayani, Moorcy, \& Sukimin, 2017). Manajemen modal memuat pengelolaan atas modal, modal ini dapat diperoleh melalui modal sendiri maupun utang yang didalamnya memuat ekuitas (Aisjah, 2012).

PT Bank BNI Syariah adalah bank hasil proses spin off dari Unit Usaha Syariah (UUS) PT Bank Negara Indonesia (Persero) Tbk yang telah beroperasi sejak 29 April 2000. BNI Syariah secara resmi beroperasi pada 19 Juni 2010 setelah mendapat Surat Keputusan Gubernur Bank Indonesia No. 12/41/KEP.GBI/2010 tanggal 21 Mei 2010.

Tabel 1. Beberapa Rasio Keuangan Bank BNI Syariah

\begin{tabular}{ccccc}
\hline Tahun & $\begin{array}{c}\text { Deposito } \\
\text { (Milyar Rupiah) }\end{array}$ & $\begin{array}{c}\text { Ekuitas } \\
\text { (Milyar Rupiah) }\end{array}$ & $\begin{array}{c}\text { Size } \\
\text { (Milyar Rupiah) }\end{array}$ & $\begin{array}{c}\text { ROA } \\
(\%)\end{array}$ \\
\hline 2012 & 3.702 & 1.187 & 10.645 & 1,48 \\
\hline 2013 & 4.914 & 1.305 & 14.709 & 1,37 \\
\hline 2014 & 8.873 & 1.950 & 19.492 & 1,27 \\
\hline 2015 & 10.405 & 2.216 & 23.018 & 1,43 \\
\hline 2016 & 12.691 & 2.487 & 28.314 & 1,44 \\
\hline 2017 & 14.221 & 3.807 & 34.822 & 1,31 \\
\hline 2018 & 15.682 & 4.242 & 41.049 & 1,42 \\
\hline 2019 & 16.137 & 4.735 & 49.980 & 1,82 \\
\hline
\end{tabular}

Sumber: Laporan Keuangan Bank BNI Syariah

Tabel 1 menunjukkan bahwa pada kenaikan deposito Bank BNI Syariah tidak diikuti kenaikan pada ROA. Hal ini bertentangan dengan penelitian yang dilakukan oleh Widya Rahmadani yang menyatakan bahwa deposito berpengaruh positif dan signifikan terhadap ROA (Rahmadani, 2019). Pertumbuhan deposito perbankan seharusnya secara otomatis dapay meningkatkan modal dari bank sehingga profitabilitas bank akan tercapai. Kenaikan ekuitas tidak diikuti pergerakan kenaikan ROA. Ekuitas yang optimal dapat digunakan untuk memaksimalkan laba dalam rangka meminimalisir kegagalan bisnis yang berorientasi pada ROA.

Kenaikan size tidak diikuti pergerakan kenaikan ROA. Hal ini bertentangan dengan penelitian sebelumnya yang menunjukkan bahwa size berpengaruh positif dan signifikan pada Return on Assets (Agam \& Pranjoto, 2021; Dewi, Arifati, \& Andini, 
Niqosiya: Journal of Economics and Business Research

Vol. 1 No. 2, Juli-Desember 2021: 152-165

2016; Sholikha, Susbiyani, \& F.a, 2019). Size atau ukuran perusahaan yang besar dapat memungkinkan suatu perusahaan untuk melakukan investasi baik untuk aktiva lancar maupun aktiva tetap serta memenuhi permintaan akan suatu produk. Hal ini mengakibatkan semakin luasnya pangsa pasar begitu juga laba perusahaan akan meningkat yang pada akhirnya dapat meningkatkan profitabilitas perusahaan. Berdasarkan permasalahan yang telah dipaparkan, penelitian ini dilakukan untuk mengetahui dan menganalisis pengaruh deposito mudharabah, ekuitas, dan size terhadap Return on Assets Bank BNI Syariah.

\section{TINJAUAN LITERATUR}

\section{Return on Assets}

Return on Assets (ROA) didefinisikan sebagai ukuran kinerja keuangan yang paling efektif dan banyak dipakai pada perbankan. Kinerja profitabilitas yang baik dapat dilihat dari peningkatan nilai ROA. Semakin tinggi ROA menunjukkan semakin tinggi laba sebelum pajak yang dihasilkan dari aset yang dimiliki oleh bank. Hail ini menunjukkan bahwa semakin besar ROA menunjukkan kinerja keuangan yang semakin baik(Akbar, 2019).

Fungsi ROA dalam kegunaan yang prinsipal atau menyeluruh sebagai keperluan kontrol dan perencanaan serta mengetahui perkembangan laba dari waktu ke waktu (Munawir, 2014). Memiliki kelebihan mampu mengukur efisiensi dalam penggunaan modal secara menyeluruh dan adanya kelemahan kesulitan dalam melakukan perbandingan rate of return antara perusahaan satu dengan lainnya (Munawir, 2014).

\section{Deposito Mudharabah}

Menurut Abdul Ghofar Anshori, deposito mudharabah merupakan simpanan masyarakat yang berupa rupiah atau valuta asing yang disimpan di bank Syariah yang penarikannya hanya dapat dilakukan sesuai dengan jangka waktu yang telah disetujui dan disepakati oleh nasabah dengan pihak bank syariah dengan berpegang teguh pada prinsip syariah (bagi hasil) menggunakan akad mudharabah (Anshori, 2018). Jangka waktu deposito biasanya 1, 3, 6 atau 12 bulan.

Deposito dapat berupa deposito berjangka dan deposito on Call. Diaplikasikan dengan prinsip Mudharabah mutlaqah dan Mudharabah Muqayyadah. Lingkup perbankan syariah menggunakan prinsip perjanjian sehingga telah dipercaya bahwa 
tidak memiliki unsur riba, maysir, dan gharar dengan menggunakan prinsip titipan (wadiah) serta prinsip bagi hasil (mudharabah) (Ismail, 2013).

\section{Ekuitas}

Menurut PSAK No.21 Tahun 2007 ekuitas merupakan hak pemilik dalam perusahaan yang berupa selisih antara aset dan kewajiban yang ada serta ukuran nilai jual perusahaan tersebut. Mengadopsi pendekatan teori kepemilikan, konsep teori entitas dan dana, melainkan ekuitas pos utama neraca memerlukan analisis. (Yahya, 2014) Ekuitas atau modal merupakan hak residual dari aset entitas syariah setelah dikurangi semua dana kewajiban dan Dana Syirkah Temporer. Ekuitas ini dapat berbentuk setoran modal dari para penanam saham, saldo keuntungan, maupun penyisihan saldo dari keuntungan. Aset dapat berupa aset lancar ataupun tetap. Sedangkan kewajiban berupa kewajiban jangka pendek maupun jangka panjang.

Sisi ekuitas terdapat 3 pos utama, yaitu modal disetor, tambahan modal disetor, saldo laba/rugi. Menurut johnson ekuitas memiliki fungsi penetapan batas maksimum pemberian kredit, penyangga penyerap kerugian. Menurut Brenton C Leavit fungsinya sebagai alat pengendalian ekspansi aktiva yang tidak tepat, melindungi deposan tidak diasuransikan (Zainur Arifin,2009). Pelaporan informasi ekuitas pemegang saham bertujuan untuk menyediakan informasi kepada yang berkepentingan tentang efisiensi dan kepengurusan manajemen serta menyediakan informasi tentang riwayat serta peluang investasi pemilik dan pemegang ekuitas lainnya. Tujuan lainnya adalah menyediakan informasi mengenai kewajiban yuridis perseroan pada para pemegang saham dan pihak lain.

\section{Size}

Perusahaan dengan skala yang besar besar memiliki biaya informasi yang rendah, tingkat kesulitan, dan dasar pemilikan yang lebih luas dibanding perusahaan dengan skala kecil. Size atau ukuran perusahaan merupakan suatu skala yang digunakan untuk mengklasifikasikan besarnya suatu perusahaan. Size perusahaan yang besar mengindikasikan bahwa perusahaan memiliki teknologi dan sistem yang baik dalam perusahaan serta memiliki kemudahan bagi manajemen untuk memanfaatkan aktiva perusahaan dalam rangka mendorong peningkatan kinerja perusahaan. 
Perusahaan dengan skala besar mempunyai pengendalian lebih besar terhadap pasar. Perusahaan tersebut memiliki kesempatan untuk meningkatkan kemampuan bersaing jika dibandingkan dengan perusahaan kecil (Umam, 2013). Perusahaan dengan skala yang besar dapat memengaruhi struktur keuangan yang dimiliki termasuk struktur pendanaannya dimana perusahaan besar akan cenderung membutuhkan dana yang besar pula untuk kemudian dapat dijadikan aset perusahaan, ini menunjukkan bahwa perusahaan berkeinginan meningkatkan pertumbuhan labanya. Pada perusahaan perbankan suatu size atau ukuran perusahaan juga dapat ditentukan layaknya perusahaan pada umumnya.

Cara dalam mengukur ukuran suatu bank dapat dilakukan dengan menggunakan Total Asset, Total Deposit, Total Capital, Risk Weighted Asset on Total Footing, Total Contingents to Total Footing. Prasetyantoko mengemukakan bahwa "Assets total dapat menggambarkan ukuran perusahaan, semakin besar Asets biasanya perusahaan tersebut semakin besar" (Prasetyantoko, 2008).

\section{METODE PENELITIAN}

Jenis penelitian yang digunakan adalah kuantitatif dengan tujuan menguji teori. Variabel yang terlibat, yaitu Deposito $\left(\mathrm{X}_{1}\right)$, Ekuitas $\left(\mathrm{X}_{2}\right)$ dan Size $\left(\mathrm{X}_{3}\right)$ sebagai variabel bebas serta Return on Assets (Y) sebagai variabel terikat. Populasi dalam penelitian ini adalah Bank Umum Syariah yang tercatat di OJK tahun 2012 - 2019. Metode purposive sampling dipilih untuk pengambilan sampel. Metode ini merupakan metode pengambilan sampel dengan menggunakan pertimbangan tertentu (Sugiono, 2018). Berdasarkan metode tersebut, sampel pada penelitian ini adalah Bank BNI Syariah. Data yang dipakai dalam analisis adalah data triwulan Bank BNI Syariah periode 20122019. Data yang diperoleh selanjutnya dianalisis dengan metode Error Correction Model dengan tahapan pengujian stasioneritas, pengujian kointegrasi, pengujian asumsi klasik, pengujian model jangka pendek, dan pengujian model jangka Panjang.

\section{HASIL DAN PEMBAHASAN}

\section{Uji Stasioneritas Data}

Uji stasioneritas dilakukan dengan uji Augmented Dickey Fuller (Uji ADF). Uji ini dilakukan sampai diperoleh semua variabel dalam penelitian ini stasioner. Uji stasioneritas pada Tabel 2 memperlihatkan bahwa tidak ada variabel yang stasioner 
pada tingkat level karena semua nilai Prob lebih dari 0,05. Pada diferensi orde 1 baru semua variabel stasioner karena semua variabel memiliki nilai Prob kurang dari 0,05.

Tabel 2. Hasil Uji Stasioneritas

\begin{tabular}{ccccc}
\hline \multirow{2}{*}{ Variabel } & \multicolumn{2}{c}{ Level } & \multicolumn{2}{c}{ Diferensi orde 1 } \\
\cline { 2 - 5 } & $\mathrm{t}_{\text {hitung }}$ & Prob & $\mathrm{t}_{\text {hitung }}$ & Prob \\
\hline Deposito & -0.942 & 0,761 & $-6,621$ & 0,000 \\
\hline Ekuitas & 0,701 & 0,990 & $-5,452$ & 0,000 \\
\hline Size & $-0,605$ & 0,971 & $-7,346$ & 0,000 \\
\hline ROA & $-2,734$ & 0,080 & $-5,145$ & 0,000 \\
\hline
\end{tabular}

Sumber: Data diolah dengan Eviews (2021)

\section{Uji Kointegrasi}

Tabel 3. Hasil Uji Kointegrasi

\begin{tabular}{cc}
\hline thitung & Prob \\
\hline$-5,460$ & 0,000 \\
\hline
\end{tabular}

Sumber: Data diolah dengan Eviews (2021)

Uji ini dilakukan sebagai persyaratan penggunaan ECM dalam analisis. Jika uji ini tidak terpenuhi, maka ECM tidak dapat diterapkan. Hasil uji kointegrasi pada Tabel 3 menunjukkan nilai Prob=0,000 yang kurang dari 0,05 sehingga terdapat kointegrasi antara variabel Deposito, Ekuitas, dan Size dengan ROA.

\section{Uji Asumsi Klasik}

Uji asumsi klasik terdiri dari uji normalitas, uji heteroskedastisitas, uji autokorelasi, dan uji multikolinieritas. Keempat uji ini harus terpenuhi pada model hubungan jangka pendek.

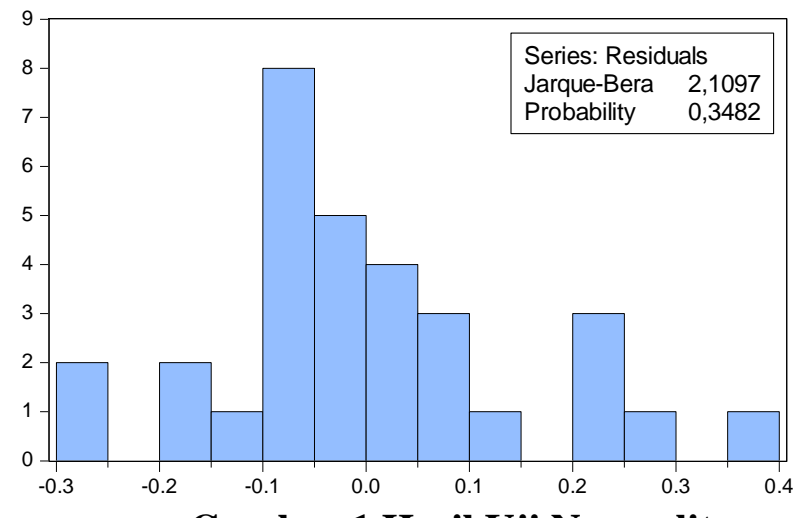

Gambar 1 Hasil Uji Normalitas 
Tabel 4. Hasil Uji Heteroskesdastisitas

\begin{tabular}{llll}
\hline $\mathrm{F}_{\text {hitung }}$ & 1,228 & Prob. $F_{\text {hitung(4,26) }}$ & 0,3230 \\
\hline Obs* ${ }^{2}$ & 4,928 & Prob. $\chi^{2}{ }_{4}$ & 0,2948 \\
\hline Scaled explained SS & 5,130 & Prob. $\chi^{2}{ }_{4}$ & 0,2742 \\
\hline
\end{tabular}

Sumber: Data diolah dengan Eviews (2021)

Tabel 5. Hasil Uji Autokolinieritas

\begin{tabular}{llll}
\hline F hitung & 0,265 & Prob. $F_{\text {hitung }(2,24)}$ & 0,769 \\
\hline Obs*R ${ }^{2}$ & 0,671 & Prob. $\chi_{2}^{2}$ & 0,715 \\
\hline
\end{tabular}

Sumber: Data diolah dengan Eviews (2021)

Tabel 6. Hasil Uji Multikoliniearitas

\begin{tabular}{cc}
\hline Variabel & Centered VIF \\
\hline $\mathrm{D}($ DEPOSITO $)$ & 2,180 \\
\hline $\mathrm{D}($ EKUITAS $)$ & 1,166 \\
\hline $\mathrm{D}($ SIZE $)$ & 2,296 \\
\hline $\mathrm{EC}(-1)$ & 1,109 \\
\hline
\end{tabular}

Sumber: Data diolah dengan Eviews (2021)

Uji normalitas pada penelitian ini dilakukan dengan Uji Jarque Bera yang ditunjukkan pada Gambar 1. Nilai probabilitas pada Gambar 1 sebesar 0,3482 lebih besar dari 0,05 sehingga residual memiliki distribusi normal. Hasil uji heteroskedastisitas dengan metode Glejser pada Tabel 4 menghasilkan nilai Prob $\chi^{2}{ }_{4}$ dari Obs $\mathrm{R}^{2}$ sebesar 0,2948 yang artinya tidak terjadi heteroskedastisitas. Untuk uji autokorelasi pada Tabel 5 memperlihatkan nilai Prob. $\chi^{2}{ }_{4}$ dari Obs $\mathrm{R}^{2}$ sebesar 0,715 lebih dari 0,05 artinya tidak terjadi autokorelasi. Hasil uji Multikolinieritas pada Tabel 6 menunjukkan bahwa semua variabel memiliki nilai centered VIF kurang dari 10 yang mengindikasikan bahwa tidak terjadi multikolinieritas pada model jangka pendek.

\section{Model Hubungan Jangka Pendek}

Tabel 7. Hasil Model Hubungan Jangka Pendek

\begin{tabular}{lccc}
\hline \multicolumn{1}{c}{ Variabel } & Koefisien & thitung & Prob. \\
\hline $\mathrm{C}$ & 0,073 & 1,694 & 0,102 \\
\hline $\mathrm{D}($ DEPOSITO $)$ & $-0,020$ & $-0,447$ & 0,659 \\
\hline $\mathrm{D}($ EKUITAS $)$ & $-0,218$ & $-1,371$ & 0,182 \\
\hline $\mathrm{D}($ SIZE $)$ & 0,001 & 0,037 & 0,972 \\
\hline $\mathrm{EC}(-1)$ & $-0,464$ & $-3,121$ & 0,004
\end{tabular}

Sumber: Data diolah dengan Eviews (2021) 
Hasil estimasi parameter model hubungan jangka pendek pada Tabel 7 dapat dituliskan sebagai berikut

$$
\Delta R O A_{t}=0,073-0,020 \Delta \text { Deposito }_{t}-0,218 \Delta \text { Ekuitas }_{t}-0,001 \Delta \text { Size }_{t}-0,464 E C_{t-1}
$$

Dari model hubungan jangka pendek dan hasil uji t dapat dijelaskan sebagai berikut

a. Konstanta sebesar 0,073 mengindikasikan bahwa ketika perubahan eposito, perubahan ekuitas, dan perubahan size serta error pada periode ke-t adalah 0 maka nilai perubahan dari ROA adalah $0,073 \%$.

b. Koefisien $\Delta$ Deposito adalah $-0,020$ mengindikasikan bahwa ketika terjadi perubahan deposito sebesar 1 Milyar rupiah pada periode ke-t, maka ROA mengalami perubahan sebesar $-0,020 \%$ dengan asumsi variabel yang lain tidak mengalami perubahan. Nilai Prob dari uji t sebesar 0,659>0,05 menunjukkan bahwa perubahan ROA tidak dipengaruhi oleh perubahan Deposito.

c. Koefisien $\Delta$ Ekuitas adalah $-0,218$ mengindikasikan bahwa ketika terjadi perubahan ekuitas sebesar 1 Milyar rupiah pada periode ke-t, maka ROA mengalami perubahan sebesar $-0,218 \%$ dengan asumsi variabel yang lain tidak mengalami perubahan. Nilai Prob dari uji t sebesar 0,182>0,05 menunjukkan bahwa perubahan ROA tidak dipengaruhi oleh perubahan Ekuitas.

d. Koefisien $\Delta$ Size adalah 0,001 mengindikasikan bahwa ketika terjadi perubahan Size sebesar 1 Milyar rupiah pada periode ke-t, maka ROA mengalami perubahan sebesar 0,001\% dengan asumsi variabel yang lain tidak mengalami perubahan. Nilai Prob dari uji t sebesar 0,972>0,05 menunjukkan bahwa perubahan ROA tidak dipengaruhi oleh perubahan Size.

e. Koefisien EC sebesar $-0,464$ berada diantara -1 dan 0 serta nilai prob=0,004 kurang dari 0,05 mengindikasikan bahwa terdapat penyesuaian hubungan jangka pendek ke jangka panjang.

Tabel 8. Hasil Uji F Model Hubungan Jangka Pendek

\begin{tabular}{cc}
\hline F & Prob \\
\hline 3,023 & 0,036 \\
\hline
\end{tabular}

Sumber: Data diolah dengan Eviews (2021)

Hasil uji F pada Tabel 8 menghasilkan nilai Prob sebesar 0,036 (lebih kecil dari 0,05) yang artinya perubahan Deposito, perubahan Ekuitas dan perubahan Size 
memberikan pengaruh pada perubahan ROA secara bersama-sama dengan besarnya kontribusi adalah $31,75 \%$.

\section{Model Hubungan Jangka Panjang}

Tabel 9. Hasil Model Hubungan Jangka Panjang

\begin{tabular}{crrr}
\hline Variabel & Koefisien & thitung & Prob. \\
\hline C & 1,008 & 10,505 & 0,000 \\
\hline DEPOSITO & $-0,044$ & $-1,478$ & 0,150 \\
\hline EKUITAS & $-0,258$ & $-1,371$ & 0,181 \\
\hline SIZE & 0,058 & 2,239 & 0,033 \\
\hline
\end{tabular}

Sumber: Data diolah dengan Eviews (2021)

Hasil estimasi parameter model hubungan jangka Panjang pada Tabel 9 dapat dituliskan sebagai berikut

$$
R O A_{t}=1,008-0,044 \text { Deposito }_{t}-0,258 \text { Ekuitas }_{t}+0,058 \text { Size }_{t}+E C
$$

Dari model hubungan jangka panjang dan hasil uji t dapat dijelaskan sebagai berikut

a. Konstanta sebesar 1,008 mengindikasikan bahwa ketika deposito, ekuitas, dan size pada periode ke-t adalah 0 maka nilai nilai ROA adalah 1,008\%

b. Koefisien deposito adalah -0,044 mengindikasikan bahwa ketika deposito mengalami kenaikan sebesar 1 Milyar rupiah pada periode ke-t, maka ROA mengalami penurunan sebesar $-0,044 \%$ dengan asumsi variabel yang lain tidak berubah. Nilai Prob dari uji t sebesar 0,150>0,05 menunjukkan bahwa ROA tidak dipengaruhi oleh deposito.

c. Koefisien Ekuitas adalah -0,258 mengindikasikan bahwa ketika terjadi kenaikan ekuitas sebesar 1 Milyar rupiah pada periode ke-t, maka ROA mengalami penurunan sebesar $-0,258 \%$ dengan asumsi variabel yang lain tidak berubah. Nilai Prob dari uji t sebesar 0,181>0,05 menunjukkan bahwa ROA tidak dipengaruhi oleh Ekuitas.

d. Koefisien Size adalah 0,058 mengindikasikan bahwa ketika terjadi kenaikan Size sebesar 1 Milyar rupiah pada periode ke-t, maka ROA mengalami kenaikan sebesar 0,058\% dengan asumsi variabel yang lain tidak berubah. Nilai Prob dari uji t sebesar 0,033<0,05 menunjukkan bahwa ROA dipengaruhi oleh Size. 
Tabel 10. Hasil Uji F Model Hubungan Jangka Pendek

\begin{tabular}{cc}
\hline F $_{\text {hitung }}$ & Prob \\
\hline 9,022 & 0,000 \\
\hline
\end{tabular}

Sumber: Data diolah dengan Eviews (2021)

Hasil uji F pada Tabel 10 menghasilkan nilai Prob sebesar 0,000 (lebih kecil dari 0,05) yang artinya Deposito, Ekuitas dan Size memberikan pengaruh pada ROA secara bersama-sama dengan besarnya kontribusi adalah $49,15 \%$.

\section{Pengaruh Deposito Mudharabah Terhadap Return on Assets}

Hasil pengujian hubungan jangka pendek maupun jangka Panjang menunjukkan bahwa Deposito Mudharabah tidak berpengaruh terhadap Return on Assets. Hasil ini mendukung penelitian yang dilakukan telah dilakukan sebelumnya yang menunjukkan bahwa deposito tidak memiliki pengaruh pada ROA(Madhani, Ismawanto, \& Sari, 2020; Mukarromah \& Badjra, 2015; Rachman, Barnas, \& Ruhadi, 2021).

Deposito yang tidak berpengaruh tersebut bisa dikarenakan selama nasabah Bank BNI Syariah memiliki produk deposito tetapi dengan jangka waktu yang pendek sehingga bank BNI Syariah belum dapat mengoptimalkan dana deposito yang ada. Sementara itu, ketika deposito mengalami penambahan dapat meningkatkan jumlah pembiayaan yang dikeluarkan, sehingga keuntungan bank semakin meningkat. Bank BNI Syariah perlu membuat suatu perencanaan untuk menarik minat nasabah dalam memilih produk deposito ini dalam jangka waktu yang lama agar bank mampu mengelola dana yang ada yang pada akhirnya dapat digunakan untuk meningkatkan laba Bank itu sendiri.

\section{Pengaruh Ekuitas Terhadap Return on Assets}

Hasil pengujian pada hubungan jangka pendek maupun jangka panjang menunjukkan bahwa ekuitas tidak berpengaruh terhadap Return on Assets. Hal ini dapat terjadi karena penggunaan ekuitas bank BNI Syariah tidak hanya terfokus dalam peningkatan laba. Bank BNI Syariah menggunakan ekuitas sebagai penunjang operasi yang lain. Bank BNI Syariah dapat mulai menggunakan ekuitas untuk meningkatkan laba dengan jalan perluasan pangsa pasar yang tidak hanya fokus pada UMKM, tetapi mulai membuka kesempatan kepada usaha-usaha yang lebih besar lagi. 
Niqosiya: Journal of Economics and Business Research

Vol. 1 No. 2, Juli-Desember 2021: 152-165

\section{Pengaruh Size Terhadap Return on Assets}

Hasil pengujian pada hubungan jangka pendek menunjukkan bahwa size tidak berpengaruh pada Return on Assets, akan tetapi dalam pengujian hubungan jangka panjang, size berpengaruh pada Return on Assets. Hasil ini mendukung penelitian sebelumnya yang menunjukkan bahwa size berpengaruh positif dan signifikan pada Return on Assets (Agam \& Pranjoto, 2021; Dewi dkk., 2016; Sholikha dkk., 2019). Koefisien Size adalah 0,058 mengindikasikan bahwa ketika terjadi kenaikan Size sebesar 1 Milyar rupiah pada periode ke-t, maka Return on Assets mengalami kenaikan sebesar $0,058 \%$ dengan asumsi variabel yang lain tidak berubah.

Besar kecilnya ukuran dari suatu bank dapat memengaruhi pendapatan yang diterima oleh bank tersebut. Ukuran bank (size) dapat dilihat dari banyaknya karyawan, nilai aset, nilai equity, serta nilai total aktiva yang dimiliki. Bank BNI Syariah dengan Size yang besar mampu menyediakan pembiayaan kepada para nasabahnya yang mengakibatkan meningkatnya profitabilitas dari bank tersebut.

\section{Pengaruh Deposito Mudharabah, Ekuitas, Dan Size Secara Simultan Terhadap Return on Assets}

Hasil pengujian hubungan jangka panjang dan hubungan jangka pendek menunjukkan bahwa deposito, ekuitas dan size memberikan pengaruh terhadap Return on Assets secara simultan. Besarnya kontribusi yang diberikan pada jangka pendek sebesar $31,74 \%$ sedangkan pada jangka panjang sebesar $49,15 \%$. Return on Assets berfungsi mengukur efektivitas perbankan yang menghasilkan laba. Semakin besar kapasitas Return on Assets, maka semakin efisien dalam menggunakan aktiva untuk mendapatkan laba yang besar. Aktiva harus dimanfaatkan dan digunakan seefisien dan semaksimal mungkin untuk meminimalisir beban yang muncul agar tingkat laba yang dihasilkan semakin membaik dan bertambah setiap kurun waktu pertahunnya.

\section{KESIMPULAN}

Hasil pengujian hubungan jangka panjang dan jangka pendek menunjukkan bahwa secara parsial deposito mudharabah dan ekuitas tidak berpengaruh terhadap Return on Assets. Secara parsial, size tidak berpengaruh terhadap Return on Assets pada jangka pendek namun berpengaruh positif pada jangka panjang. Deposito, ekuitas dan 
size memberikan pengaruh terhadap Return on Assets secara simultan baik pada hubungan jangka pendek maupun hubungan jangka panjang.

Tidak adanya pengaruh antarvariabel yang memungkinkan adanya pengelolaan deposito mudharabah dan ekuitas yang belum optimal, sehingga tidak dapat memengaruhi laba (Return on Assets). Bank BNI Syariah perlu membuat suatu perencanaan untuk menarik minat nasabah dalam memilih produk deposito dalam jangka waktu yang lama agar bank mampu mengelola dana yang ada, sehingga dapat digunakan untuk meningkatkan laba Bank itu sendiri. Bank BNI Syariah juga dapat memperluas pangsa pasar yang tidak hanya fokus pada UMKM, namun dimulai dengan membuka kesempatan kepada usaha-usaha yang lebih besar lagi.

\section{REFERENSI}

Agam, D. K. S., \& Pranjoto, G. H. (2021). Pengaruh CAR, LDR, BOPO, dan Size Terhadap ROA pada Sektor Perbankan yang Terdaftar di BEI 2015-2019. Jurnal Kajian Ilmu Manajemen (JKIM), 1(2). https://doi.org/10.21107/jkim.v1i2.11597

Aisjah, S. (2012). Strategi Diversifikasi Korporat ( Penciptaan Nilai Perusahaan). Malang: UB Press.

Akbar, T. (2019). Kajian Kinerja Profitabilitas Bank Pada Perspektif Bank Umum Berdasarkan Kegiatan Usaha. Ponorogo: Uwais Inspirasi Indonesia.

Anshori, A. G. (2018). Perbankan Syariah Di Indonesia. Yogyakarta: Gajah Mada University Press.

Apriyanti, R., Rahman, A. A., \& Maharani, S. (2021). EMPIRICAL STUDIES OF THE EFFECT OF OPERATIONAL COSTS AND OPERATING INCOME, FINANCING TO DEPOSIT RATIO AGAINST RETURN ON ASSET WITH NON-PERFORMING FINANCING AS INTERVENING VARIABLES IN SHARIA BANK INDONESIA 2013-2020. Niqosiya: Journal of Economics and Business Research, 1(1), 21-36. https://doi.org/10.21154/niqosiya.v1i1.78

Awintasari, L., \& Nurhidayati, M. (2021). PENGARUH NON PERFORMING FINANCING, CAPITAL ADEQUACY RATIO, BEBAN OPERASIONAL PENDAPATAN OPERASIONAL DAN NET IMBALAN TERHADAP RETURN ON ASSETS (STUDI PADA BANK MAYBANK SYARIAH PERIODE 2012-2019). Niqosiya: Journal of Economics and Business Research, 1(1), 78-93. https://doi.org/10.21154/niqosiya.v1i1.108

Dewi, F. S., Arifati, R., \& Andini, R. (2016). ANALYSIS OF EFFECT OF CAR, ROA, LDR, COMPANY SIZE, NPL, AND GCG TO BANK PROFITABILITY (CASE STUDY ON BANKING COMPANIES LISTED IN BEI PERIOD 20102013). Journal Of Accounting, 2(2). Diambil dari http://jurnal.unpand.ac.id/index.php/AKS/article/view/465

Ernayani, R., Moorcy, N. H., \& Sukimin. (2017). FAKTOR-FAKTOR YANG MEMPENGARUHI RETURN ON ASSETS (Studi Pada Bank Umum Syariah Di Indonesia Periode 2011-2016). Prosiding Seminar Nasional dan Call For Paper Ekonomi dan Bisnis (SNAPER-EBIS 2017), 284-293. Jember. 
Hidayat, W. W. (2018). DASAR-DASAR ANALISA LAPORAN KEUANGAN. Uwais Inspirasi Indonesia.

Indriwati, L., \& Purwana, A. E. (2021). PENGARUH CAPITAL ADEQUACY RATIO, INFLASI, DAN GROSS DOMESTIC PRODUCT TERHADAP RETURN ON ASSETS (STUDI PADA BANK UMUM SYARIAH NON DEVISA DI INDONESIA PERIODE TAHUN 2018-2020). Niqosiya: Journal of Economics and Business Research, 1(1), 110-122. https://doi.org/10.21154/niqosiya.v1i1.90

Ismail. (2013). Manajemen Perbankan dari Teori Menuju Aplikasi. Jakarta: Kencana. Ismail. (2020). Perbankan Syariah. Jakarta: Kencana.

Kasmir. (2014). Analisis Laporan Keuangan (1 ed.). Jakarta: Raja Grafindo Persada.

Madhani, Y. A., Ismawanto, T., \& Sari, D. H. (2020). PENGARUH DEPOSITO MUDHARABAH, TABUNGAN MUDHARABAH, DAN PEMBIAYAAN MUDHARABAH TERHADAP RETURN ON ASSETS (ROA)(Studi Kasus pada PT. Bank BNI Syariah (Persero), Tbk. Periode 2010-2019). JMAP: Jurnal Tugas Akhir Mahasiswa Akuntansi Poltekba, 2(1), 378-392.

Mukarromah, L., \& Badjra, I. B. (2015). Pengaruh Pertumbuhan Tabungan, Deposito dan Kredit terhadap Pertumbuhan Profitabilitas PT BPR Partakencana Tohpati Denpasar. E-Jurnal Manajemen Unud, 4(8), 2286-2300.

Munawir. (2014). Analisa Laporan Keuangan. Yogyakarta: Liberty.

Prasetyantoko. (2008). Corporate Governance. Jakarta: Gramedia Pustaka Utama.

Pravasanti, Y. A. (2018). Pengaruh NPF dan FDR Terhadap CAR dan Dampaknya Terhadap ROA Pada Perbankan Syariah Di Indonesia. Jurnal Ilmiah Ekonomi Islam, 4(03), 148-159. https://doi.org/10.29040/jiei.v4i03.302

Rachman, A. R., Barnas, B., \& Ruhadi. (2021). Pengaruh Deposito Mudharabah dan NPF Terhadap ROA dan Pembiayaan Bagi Hasil Sebagai Intervening pada Bank Umum Syariah. Journal of Applied Islamic Economics and Finance, 2(1), 499510.

Rahmadani, W. (2019). Pengaruh Pendapatan Bagi Hasil Deposito Mudharabah Terhadap Roa ( Study Empiris pada Bank BNI Syariah Tahun 2013-2015). Islamic Banking: Jurnal Pemikiran Dan Pengembangan Perbankan Syariah, 5(1), 53-64. https://doi.org/10.36908/isbank.v5i1.69

Rahmawati, D. (2017). Analisis Pengaruh Pembiayaan Mudharabah, Musyarakah, Murabahah dan Inflasi terhadap Profitabilitas (ROA) Bank Umum Syariah Di Indonesia Periode 2011-2015. UIN Syarif Hidayatullah, Jakarta.

Riyanto, I. S., \& Asakdiyah, S. (2020). ANALISIS PENGARUH INFLASI, JUMLAH UANG BEREDAR, DAN PRODUK DOMESTIK BRUTO TERHADAP RETURN ON ASSET (ROA) BANK SYARIAH DI INDONESIA. Jurnal Fokus Manajemen Bisnis, 6(2), 132-143.

Sholikha, I., Susbiyani, A., \& F.a, I. K. (2019). Pengaruh Corporate Social Responsibility, Leverage dan Size terhadap Profitabilitas. International Journal of Social Science and Business, 3(3), 272-280. https://doi.org/10.23887/ijssb.v3i3.21053

Sugiono. (2018). Metode Penelitian Kuantitatif. Bandung: Alfabeta.

Umam, K. (2013). Manajemen Perbankan Syariah. Bandung: CV. Pustaka.

Wahyuni, S. (2019). Perbankan Syariah: Pendekatan Penilaian Kinerja. Pasuruan: Qiara Media.

Yahya, R. (2014). Akuntansi Perbankan Syariah Teori Dan Praktik Kontemporer (2 ed.). Jakarta: Salemba Empat. 